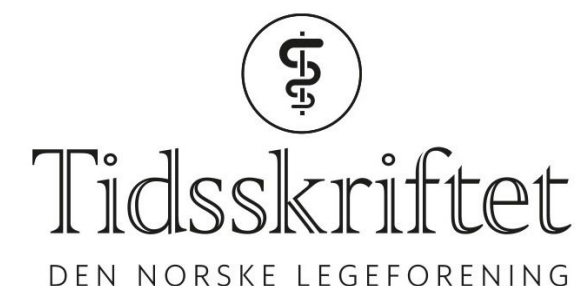

\title{
Hvordan kan strykprosenten ved eksamen stabiliseres?
}

RETTELSE

ANDERS BARLI COLBERG

DANIEL VATN

RUNE STANDAL

MARIA RADTKE

TOBIAS S. SLØRDAHL

Tidsskr Nor Legeforen 2017; 137: 1601-6

I Tidsskriftet nr. 20/2017 s. 1604 skal det i tabell 2, 1. rad, 4. kolonne (Gjennomsnittsskår) stå 78,7. På side 1606 i figur 3 skal som tekst langs X-aksen stå: Eksamener 2010-15 (ikke Kuluminerte eksamener).

Vi beklager feilen, den er rettet på nett.

Publisert: 28. november 2017. Tidsskr Nor Legeforen. DOI: 10.4045/tidsskr.17.0947

(C) Tidsskrift for Den norske legeforening 2020. Lastet ned fra tidsskriftet.no 